OPEN ACCESS

Edited by:

Patrizia Porcu,

Institute of Neuroscience (CNR), Italy

Reviewed by:

Jennifer Cummings,

University of Michigan, United States

Elaine M. Hull,

Florida State University, United States

${ }^{*}$ Correspondence:

Mary K. Holder

mary.holder@psych.gatech.edu

tThese authors have contributed equally to this work

Specialty section:

This article was submitted to Motivation and Reward, a section of the journal Frontiers in Behavioral

Neuroscience

Received: 30 June 2019

Accepted: 19 August 2019

Published: 10 September 2019

Citation:

Rudzinskas SA, Williams KM, Mong JA and Holder MK (2019) Sex,

Drugs, and the Medial Amygdala: A

Model of Enhanced Sexual

Motivation in the Female Rat.

Front. Behav. Neurosci. 13:203 doi: 10.3389/fnbeh.2019.00203

\section{Sex, Drugs, and the Medial Amygdala: A Model of Enhanced Sexual Motivation in the Female Rat}

\author{
Sarah A. Rudzinskas ${ }^{1 \dagger}$, Katrina M. Williams ${ }^{2 \dagger}$, Jessica A. Mong ${ }^{1,3}$ and Mary K. Holder ${ }^{4 *}$ \\ ${ }^{1}$ Program in Neuroscience, University of Maryland, Baltimore, MD, United States, ${ }^{2}$ Department of Veterans Affairs, Geriatric \\ Research Education and Clinical Center, Baltimore, MD, United States, ${ }^{3}$ Department of Pharmacology, University of \\ Maryland, Baltimore, MD, United States, ${ }^{4}$ School of Psychology, Georgia Institute of Technology, Atlanta, GA, United States
}

Methamphetamine (METH) is a psychomotor stimulant that is reported to enhance sexual desire and behavior in both men and women, leading to increases in unplanned pregnancies, sexually-transmitted infections, and even comorbid psychiatric conditions. Here, we discuss our rodent model of increased sexually-motivated behaviors in which the co-administration of METH and the ovarian hormones, estradiol and progesterone, intensify the incentive properties of a sexual stimulus and increases measures of sexuallymotivated behavior in the presence of an androgen-specific cue. We then present the neurobiological mechanisms by which this heightened motivational salience is mediated by the actions of METH and ovarian hormones, particularly progestins, in the posterodorsal medial nucleus of the amygdala (MePD), a key integration site for sexually-relevant sensory information with generalized arousal. We finally demonstrate the cellular and molecular mechanisms underlying this facilitation of sexual motivation by $\mathrm{METH}$, including the upregulation, increased phosphorylation, and activation of progestin receptors (PRs) in the MePD by METH in the presence of ovarian hormones. Taken together, this work extends our understanding of the neurobiology of female sexual motivation.

Keywords: methamphetamine, dopamine, proceptive behavior, progesterone, sexual motivation, medial amygdala

\section{INTRODUCTION}

Sexual behaviors are a complex, coordinated suite of actions that arise from the integration of psychological and physiological processes with external elements. One key component of sexual behaviors is that of sexual motivation, a hypothetical, internal willingness to engage in sexual behaviors (Holder and Mong, 2017). Although research into female sexual motivation is an active and growing field, relatively little is understood about the neurobiological origins of sexual motivation in women. Many of these mechanistic questions cannot be currently answered in women, so rat models are most frequently used to study sexual motivation and behavior (Pfaus et al., 2003; Blaustein, 2008).

In this review article, we discuss the modulators of female sexual motivation, using the concept of incentive motivation as a foundational working model. Next, we summarize what is known in regard to the neurobiology of female sexual motivation in rats. We then describe our methamphetamine (METH) model of increased sexually-motivated behaviors in female rats. We finally detail insights into the neurobiology and mechanisms of enhanced female sexual motivation gained using this model. 


\section{RODENT SEXUAL BEHAVIORS}

The female rats show a wide range of specific sexual behaviors that are displayed in the presence of a male rat. Following anogenital investigations, the female will typically engage in approach and solicitation behaviors, which serve to initiate sexual contact with a male (McClintock and Adler, 1978; Erskine, 1989; Pfaus et al., 2003). The female approaches the male with a head-wise orientation then quickly runs away (Pfaus et al., 2003). This runaway takes the form of proceptive behaviors such as hopping and darting, with and without ear wiggling, in a traditional behavioral arena (Madlafousek and Hlinák, 1983). Hopping is distinct from general locomotion as it is a rapid, stiff-legged upward jump, followed by a bow-shaped return to the floor, and ends in a crouch. A hop covers the distance of approximately one extended body length (Madlafousek and Hlinák, 1977). Darting is a specialized form of a runaway from the male in which the female accelerates swiftly, using rapid low steps with the body held near the floor (Hemmingsen, 1933; Beach, 1942). The series of hopping-and-darting typically ends with a presentation behavior, or a pre-lordotic crouch (Madlafousek and Hlinák, 1977). This crouch serves to help support the male's mounting behaviors. Upon a successful mount by the male, the female rat displays a behavioral reflex known as lordosis, in which the female arches her back, elevates her head and rump, and deflects her tail to one side (reviewed in Erskine, 1989). Proceptive behaviors typically precede the first lordosis during the period of sexual receptivity, and the numbers of proceptive events increase in the minute preceding lordosis (Chu and Ågmo, 2015). Indeed, females that display more proceptive behaviors are pursued more frequently by males (Chu and Ågmo, 2014). In addition, the female's display of proceptive behaviors precedes nearly all male sexual behaviors (Bergheim et al., 2015).

In arenas that allow for separation between the male and female rat, such as a paced mating arena with escape chamber(s) or bilevel chambers, the female rat controls the tempo and occurrence of the sexual behaviors (McClintock and Adler, 1978; Erskine and Baum, 1982; Erskine, 1985; Pfaus et al., 2003). If female rats are given the opportunity to choose between two males, they display a consistent partner preference, as indicated by increased time with a preferred male and by returning to him more rapidly in a paced-mating environment even across multiple encounters (Lovell et al., 2007).

\section{MODULATORS OF SEXUAL MOTIVATION}

\section{Central Motive State}

There are two necessary components of any motivated behavior: (i) the incentive properties of an external stimulus; and (ii) a central motive state (Bindra, 1974; Ågmo, 1999). The external stimulus has incentive or aversive qualities that serve to influence the hedonic, or pleasurable values. Incentive stimuli create a tendency for an individual to approach the object; whereas, aversive stimuli create a tendency for avoidance behaviors (Bindra, 1974). The central motive state is the integration of the physiological processes, such as hormones, with the neural processes that direct the motivational behaviors (Bindra, 1974;
Ågmo, 1999). It is the interplay between the incentive qualities of the stimulus and the central motive state that ultimately determine the likelihood of a particular behavioral response, whether it be approach or avoidance behaviors (Figure 1).

One major assumption of the central motive hypothesis is that of the hedonic value of the external stimulus. In order to apply this hypothesis to the study of female sexual motivation, it must, therefore, be established that females engage in sexual behavior to experience sexual pleasure (Pfaus et al., 2003; Ågmo, 2007). Sexually-motivated female rats lever press (Bermant, 1961; French et al., 1972), cross an electrified grid (Meyerson and Lindström, 1973), and nose-poke (Matthews et al., 1997; Cummings and Becker, 2012) to gain access to a sexually-active male. When female rats can pace sexual behavior, as in bilevel arenas or those with escape chambers, they show conditioned place preference in that they spend more time in the portion of an arena in which a sexual encounter occurred (Paredes and Alonso, 1997; Meerts and Clark, 2007). Subsequent studies indicate that female rats will only develop this conditioned place preference when copulation is at their preferred pacing interval (Jenkins and Becker, 2003b). Finally, female rats show evidence of orgasm-like behavior as indicated by contractions of the pelvic-floor muscles and short-term changes associated with reward state such as ultrasonic vocalizations (USVs; Pfaus et al., 2016). Taken together, these studies indicate that sexual behavior may, in itself, be rewarding to the female rat, at least under certain conditions.

The central motive state determines the external stimulus's incentive value through modulation of the hedonic value of that stimulus (Berridge, 2004). It would then follow that changes to the central motive state could increase the attractivity to a sexually-relevant stimulus (Pfaus et al., 2003; Ågmo, 2007). That is, an increased activation of the central motive state would enhance the strength of behavioral responses toward sexually-salient cues. This may take the form of more olfactory investigations and displays of the solicitation, proceptive, and pacing behaviors in the presence of a male rat. In addition, it is possible that this enhanced activation of the central motive would also lead to the abolition of mate preferences, as the same sensory cues may increase in incentive qualities.

We can conceive of the central motive state as arising from two components: (i) a generalized state common to all forms of motivated behavior; and (ii) a specific drive that depends on physiological needs (Pfaff, 1999). The first component is generalized arousal which energizes all motivated behaviors (Pfaff et al., 2008). The specific neurobiological signals known to mediate the sexual motivation and behavior in the female rat are the ovarian hormones estradiol and progesterone (Cummings and Becker, 2012; Uphouse et al., 2015). Although these are not the only neurobiological factors that could alter the central motive state to lead differences in sexual motivated behaviors, we will focus discussion on the factors of generalized arousal and ovarian hormones in this review article.

\section{Generalized Arousal}

Generalized arousal is a hypothetical construct that energizes all behavioral processes by promoting wake, alertness, and 


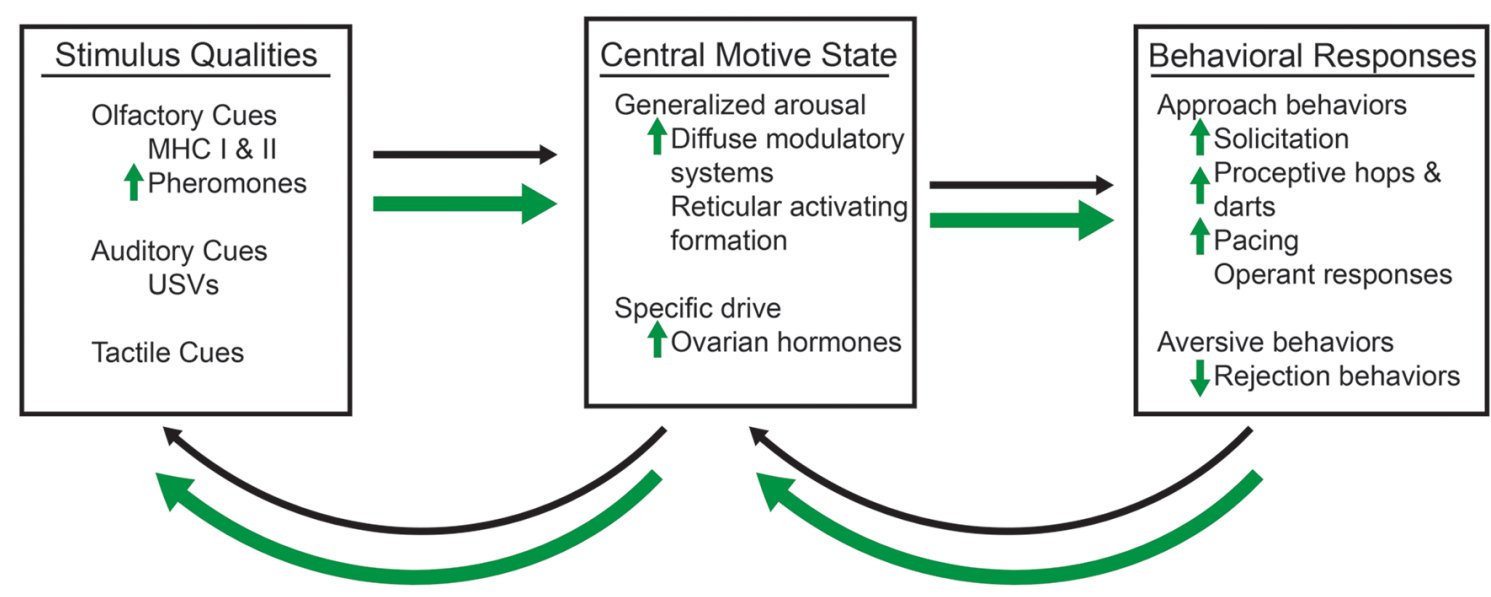

FIGURE 1 | A conceptual model of sexual motivation, which are represented by thin, black arrows and enhancements by methamphetamine (METH), which are represented by thick, green arrows. The olfactory, such as the major histocompatibility complex I and II (MHC I and MHC II), which contribute to pheromones, auditory, such as ultrasonic vocalizations (USVs), and tactile, such as the flank stimulation, qualities of a sexual stimulus interact with the central motive state, which itself is modulated by the generalized arousal state and the activation of a specific drive (e.g., the presence of ovarian hormones and activation of their cognate receptors). METH requires the activation of dopaminergic and progestin receptors (PRs) to enhance the activation of the central motive state and female sexual motivation. The presence of a sexual stimulus and activation of the central motive state then influences the likelihood of sexual behavioral responses, which then have the ability to feedback and alter the central motive state itself. Changes to the central motive state then feedback to alter the salience of particular qualities of the sexual stimulus. METH increases the salience of androgen-specific cues of a sexual stimulus, which in term lead to increases in display of solicitations, proceptive hops and darts, and paced mating behaviors. There is also a decrease in the number of rejection behaviors.

responses to and interaction with the environment (Pfaff et al., 2008). Generalized arousal has been demonstrated by: (i) a responsiveness to sensory stimuli across multiple modalities; (ii) motor activity; and (iii) emotional or affective reactivity (Pfaff et al., 2008). The ascending, diffuse neuromodulatory systems that form the reticular activating formation contribute to generalized arousal. Noradrenergic projections to the cerebral cortex modulate the sensory responsiveness, whereas the nigrostriatal dopaminergic projections mediate the motor activity directed towards salient stimuli (Pfaff et al., 2008). Mesolimbic dopaminergic projections, which comprise part of the natural reward circuit, facilitate the incentive salience, or the "wanting" of some stimulus (reviewed in Berridge, 2007, 2019). As such, certain types of sexual behaviors (e.g., femalepaced sexual behavior) will result in a release of dopamine in the nucleus accumbens (Jenkins and Becker, 2003a). Further, the administration of agonists of noradrenergic or dopaminergic receptors will enhance, and antagonists will reduce, measures of female sexual behavior (Foreman and Moss, 1979; FernándezGuasti et al., 1985a,b, 1987; Grierson et al., 1988; Petitti and Etgen, 1990; Chu and Etgen, 1999; Chu et al., 1999). Thus, both neurotransmitters appear to work in conjunction to modulate general arousal and prime a female towards sexual behavior.

\section{Ovarian Hormones}

The period of sexual receptivity in rats is limited to a few hours prior to the onset of ovulation (Nequin et al., 1979; Freeman, 1994). Several classic studies have demonstrated the role of both estradiol and progesterone in triggering both proceptive and receptive sexual behaviors in the rat (Beach, 1976). High levels of estradiol are sufficient and activation of the estrogen receptors
(ERs) is necessary to induce lordosis behaviors; however, the intensities of lordosis, based on the degree of spinal curvature, is highly variable with frequent displays of rejection behaviors (Boling and Blandau, 1939; Beach et al., 1942; Whalen, 1974; Spiteri et al., 2010). Progesterone increases the efficacy of estradiol in the induction of lordosis. In addition, progesterone and the activation of the PRs is necessary for the occurrence of the solicitation, proceptive, and paced mating behaviors (Boling and Blandau, 1939; Beach et al., 1942; Beach, 1976; Whalen, 1974; Fadem et al., 1979; Tennent et al., 1980; Edwards and Pfeifle, 1983; Olster and Blaustein, 1988; Blaustein, 2008). These hormones strongly affect the responses to olfactory and tactile stimuli, with modest effects on generalized arousal (Chu et al., 2015), providing evidence that the ovarian hormones contribute to the central motive state to modulate the incentive qualities of the male rat.

\section{NEUROBIOLOGY OF SEXUAL MOTIVATION}

The historical focus of the neurobiology of female sexual behavior has been focused on the neurocircuit that controls lordosis. As lordosis is a behavioral reflex, the neural mechanisms of it are more readily elucidated than the neural mechanisms of sexual motivations. The lordosis circuit has been exquisitely detailed using multilateral approaches including electric stimulation and lesions of each of the nuclei in the circuit (Mathews and Edwards, 1977; Davis et al., 1979; Pfaff and Sakuma, 1979; Sakuma and Pfaff, 1979; Brink and Pfaff, 1980; Schwartz-Giblin and Pfaff, 1980; Femano et al., 1984a,b), patterns of neuronal activation (Flanagan et al., 1993; Tetel et al., 
1993; Flanagan-Cato and McEwen, 1995; Polston and Erskine, 1995; Pfaus et al., 1996; Pfaus and Heeb, 1997), and viral tract tracing studies to map the anatomical connections (Daniels et al., 1999). Of primary importance for lordosis is the ventrolateral portion of the ventromedial nucleus of hypothalamus (VMN; reviewed in Pfaff et al., 1994). The ovarian hormones serve to activate the neurons of the VMN, which then overcomes the tonic inhibition on lordosis (Powers and Valenstein, 1972; Moss et al., 1974; Pfaff and Sakuma, 1979; Kow et al., 1985; Fahrbach et al., 1989).

The mechanisms and the neural circuitry controlling female sexual motivation have not been as well elucidated. Furthermore, if motivated behavior arises from both the incentive properties of a sensory stimulus and mediators of the central motive state, it is likely that the neural circuitry that processes these sensory cues also contribute to sexual motivation. The work of ourselves and others indicates that sexual motivation arises from an interplay of activation of the natural reward circuity and the processing of olfactory cues in the limbic/hypothalamic social behavior circuitries.

The posterodorsal nucleus of the medial amygdala (MePD) is a good candidate region for the regulation of sexual motivation and the modulation of the output sexual behavior (Mascó and Carrer, 1980, 1984; Erskine, 1989; Kondo and Sakuma, 2005; Afonso et al., 2009). Changes to generalized arousal would influence the activation of the MePD as it receives both noradrenergic and dopaminergic input (Gray, 1999; Pitkänen, 2000). The MePD contains both ERs and PRs (Pfaff and Keiner, 1973; Simerly et al., 1990), making it sensitive to the specific drivers of sexual motivation. The MePD also receives chemosensory signals of pheromones from the accessory olfactory bulb (Keller et al., 2009), so it would be activated by sexually relevant olfactory cues. The projections of the MePD target and can activate several key output nuclei involved in social and sexual behaviors including the VMN (Kevetter and Winans, 1981; Simerly, 2002; Keller et al., 2009). Finally, lesions of the MePD lead to fewer lordosis responses (Mascó and Carrer, 1984), proceptive behaviors (Mascó and Carrer, 1980; Afonso et al., 2009), and a reduction in conditioned place preference (GarcíaHorsman et al., 2008) and sensitivity to sexual stimulation (Guarraci, 2010).

\section{METHAMPHETAMINE INCREASED MEASURES OF SEXUAL MOTIVATION TOWARDS AN INCENTIVE STIMULUS}

To better explore the neurobiology of sexual motivation in females, we created a model of enhanced motivation by administering METH. METH is a drug of abuse that intensifies sexual drives, desires, and sexual activities in women (Rawson et al., 2002; Semple et al., 2004a). In addition, METH use is also associated with a more pleasurable sexual experience (Lorvick et al., 2012). These anecdotal and clinical self-reports are supported by the increased rates of sexually-transmitted infections and of unplanned pregnancies (Semple et al., 2004b; Mansergh et al., 2006). As users of METH tend to administer it several times over the course of a few days (Haile et al., 2009), we administer METH (5 mg/kg/day) once a day for 3 days to ovariectomized female rats at the same time as the ovarian hormones estradiol benzoate and progesterone (Holder et al., 2010). The optimal time to test for female sexual behavior is 4-6 $\mathrm{h}$ following the administration of progesterone (Nequin et al., 1979; Freeman, 1994). Importantly, neither stereotyped behavior nor hyper-locomotor behavior are present 4-6 h after METH administration, suggesting that any increase in sexual behavior due to METH reflects heightened sexual motivation, not motor responses (Holder et al., 2010).

The acute administration of METH enhances measures of sexual motivation in hormonally-primed female rats (Holder and Mong, 2010; Holder et al., 2010; Winland et al., 2011). METH treatment increases the lordosis response in addition to doubling the frequency of proceptive behavior of hops, darts, and ear-wiggles (Figure 2A; Holder et al., 2010). When tested in a paced-mating arena, female rats treated with METH are less likely to leave the male rat following sexual stimulation, and if they leave, they return to him more rapidly compared to saline-treated, hormonally-primed females (Holder et al., 2010; Winland et al., 2011). In addition, these METH-treated female rats displayed more solicitation and proceptive behaviors, especially during the post-ejaculatory interval (Holder and Mong, 2010). The possibility remains that METH may alter the timing and displays of sexual behavior instead of sexual motivation per se; however, there is growing evidence that motivation and timing of behaviors are not independent processes such that changes to the hedonic value lead to alterations in interval duration, indicating that the changes in timings of a behavior are produced by changes in motivational state (reviewed in Galtress et al., 2012). While the decreased latency to return to the male is suggestive of an increased tempo for sexual behavior, the timing aspects should be further explored using more direct measures of sexual motivation in female rats (e.g., operant responding).

METH may also alter the preferences of specific sexual partners based upon relevant sensory cues. For example, METH-treated, hormonally-primed female rats make more approaches and spend more time with a potential sexual partner (e.g., a male or a castrated male treated with dihydrotestosterone) compared to a non-sexual partner (e.g., a female or a castrated male; Winland et al., 2011; Rudzinskas and Mong, 2016). Dihydrotestosterone provides the necessary androgen-mediated cues, such as pheromones (Orsulak and Gawienowski, 1972; Drewett and Spiteri, 1979), sufficient to elicit solicitation, hops, and darts, with METH treatment increasing the number of proceptive behaviors (Figure 2B; Rudzinskas and Mong, 2016). These pheromonal cues are olfactory in nature, and while there are no differences in anogenital investigations induced by $\mathrm{METH}$, there are significantly fewer sniffing behaviors. Consistent with an increase in generalized arousal as part of the central motive state, this work suggests that METH may enhance the detection of olfactory cues. Future work is necessary to explore the potential effects of METH on olfaction. Taken together, these data suggest that METH does not alter the ability of females to discriminate between stimuli, but rather enhances 


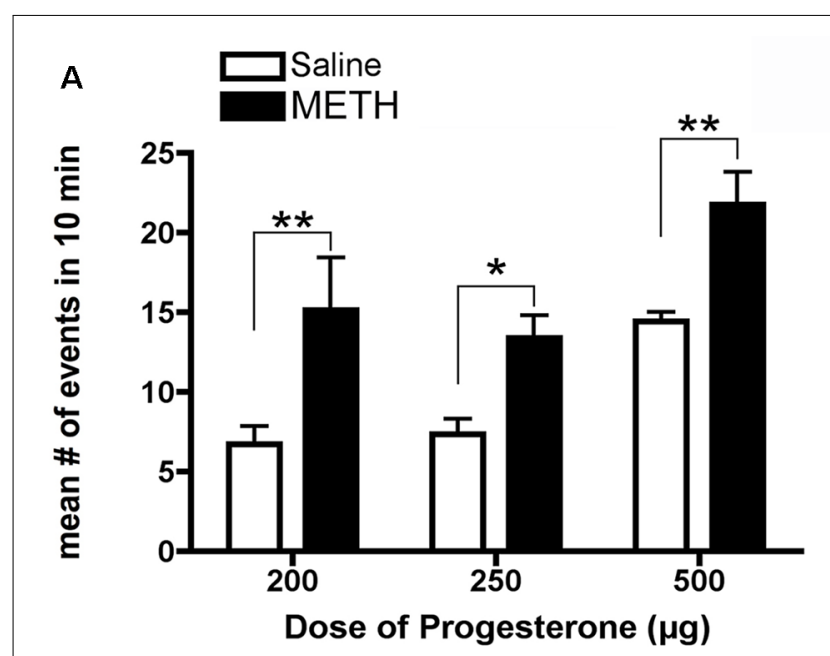

B

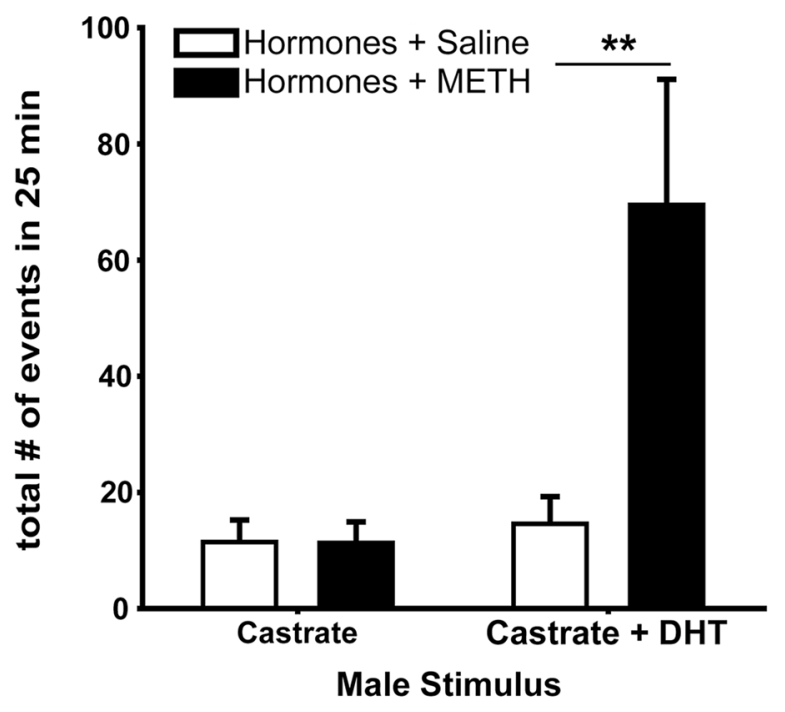

FIGURE 2 | The enhancement of sexually-motivated behaviors by METH. (A) METH treatment doubles the number of proceptive events displayed in 10 min regardless of progesterone $(P)$ dose, compared to the respective saline-treated females. (B) Replacement of androgen-specific cues in castrated males induces more markedly increased proceptive behaviors in hormonally-primed female rats treated with METH. Data represents means \pm standard error of the mean (SEM); ${ }^{*} p<0.05,{ }^{* *} p<0.01$. Reprinted with permission from Elsevier, Inc., Amsterdam, Netherlands.

central motive state arousal to increase sexual motivation in a context-specific manner by potentiating the behavioral responses towards an incentive stimulus.

\section{A LOCUS FOR ENHANCED SEXUAL MOTIVATION}

The combination of METH and ovarian hormones enhances the measures of sexual motivation; therefore, we hypothesized that METH would converge with ovarian hormone actions to increase neuronal activity and induce neuroplasticity of the neurocircuitry that underlies sexual motivation and behavior.
There is an additive effect of METH and ovarian hormones on the expression of cFos, an immediate early gene that is used as a marker of neuronal activation, in both the MePD and VMN (Figure 3A; Holder et al., 2010; Williams and Mong, 2017). The MePD projects to and can activate the VMN (Kevetter and Winans, 1981; Simerly, 2002; Keller et al., 2009). Therefore, it is likely that the increase in cFos in the VMN follows the increase in neuronal activation of the MePD. In further support, spinophilin, a cytoskeleton-associated protein found in dendrite spines, has a $60 \%$ increase in the MePD, but not the VMN, following the administration of METH and ovarian hormones (Figure 3B; Holder and Mong, 2010). This increase in spinophilin suggests that METH and ovarian hormones synergize to increase the density of dendritic spines and, thus, synaptic connectivity in the MePD. Taken together, the increase in neuronal activation and spinophilin in the MePD suggest that the METH-induced enhancement of female sexual motivation and behavior arise from converging actions of the ovarian hormone in the MePD.

It has been previously reported that lesions of the MePD do not abolish the expression of female sexual behavior, but rather, reduces the expression of sexually-motivated behaviors (Mascó and Carrer, 1980, 1984; Afonso et al., 2009). Lesions of the MePD also prevent the $\mathrm{METH}$-induced increase in proceptive behaviors (Figure 3C; Holder et al., 2015). The Daun02 inactivation techniques allow for a more precise investigation of the cells activated in the MePD and the interactions of METH and ovarian hormone signaling on sexually motivated behaviors. Briefly, neuronal activation induces both cFos and $\beta$-galactosidase expression in Sprague-Dawley cFos-lacZ trans-genetic rats (Koya et al., 2016). The $\beta$-galactosidase both serves as another method of visualizing activated neurons, but it also converts the prodrug Daun02 into daunorubincin, which then triggers apoptosis of the activated cell populations (Santone et al., 1986; Farquhar et al., 2002; Pfarr et al., 2015). Therefore, this Daun02 inactivation technique produces selective lesions of the cells that are activated by METH and/or ovarian hormones. As with the cFos expression, the combination of METH and ovarian hormones produces an increase of $\beta$-galactosidase over that of ovarian hormones in a discrete population of cells within the MePD (Figures 3D,E; Williams and Mong, 2017). In addition, successful Daun02 lesions of this neuronal ensemble reduce the proceptive behaviors to baseline levels, further supporting the notion that the MePD utilizes signals from METH on hormonally responsive neurons to augment the behavioral response (Figure 3F; Williams and Mong, 2017). Furthermore, the Daun02 inactivation does not alter receptive/reflexive sexual behaviors, supporting the MePD's role as an integration center specifically for sexual motivation. Taken together, these results indicate a synergy of intracellular signaling cascades induced by METH and ovarian hormones within MePD cells. This will be further explored in subsequent sections.

One way in which this synergy of intracellular signaling cascades could result in an increase in sexual motivation is via changes in epigenetic modifications, which can then lead to marked changes in gene expression. These epigenetic changes could occur on the DNA directly, leading to localized regulation of gene transcription, or by modification of the histones, an 

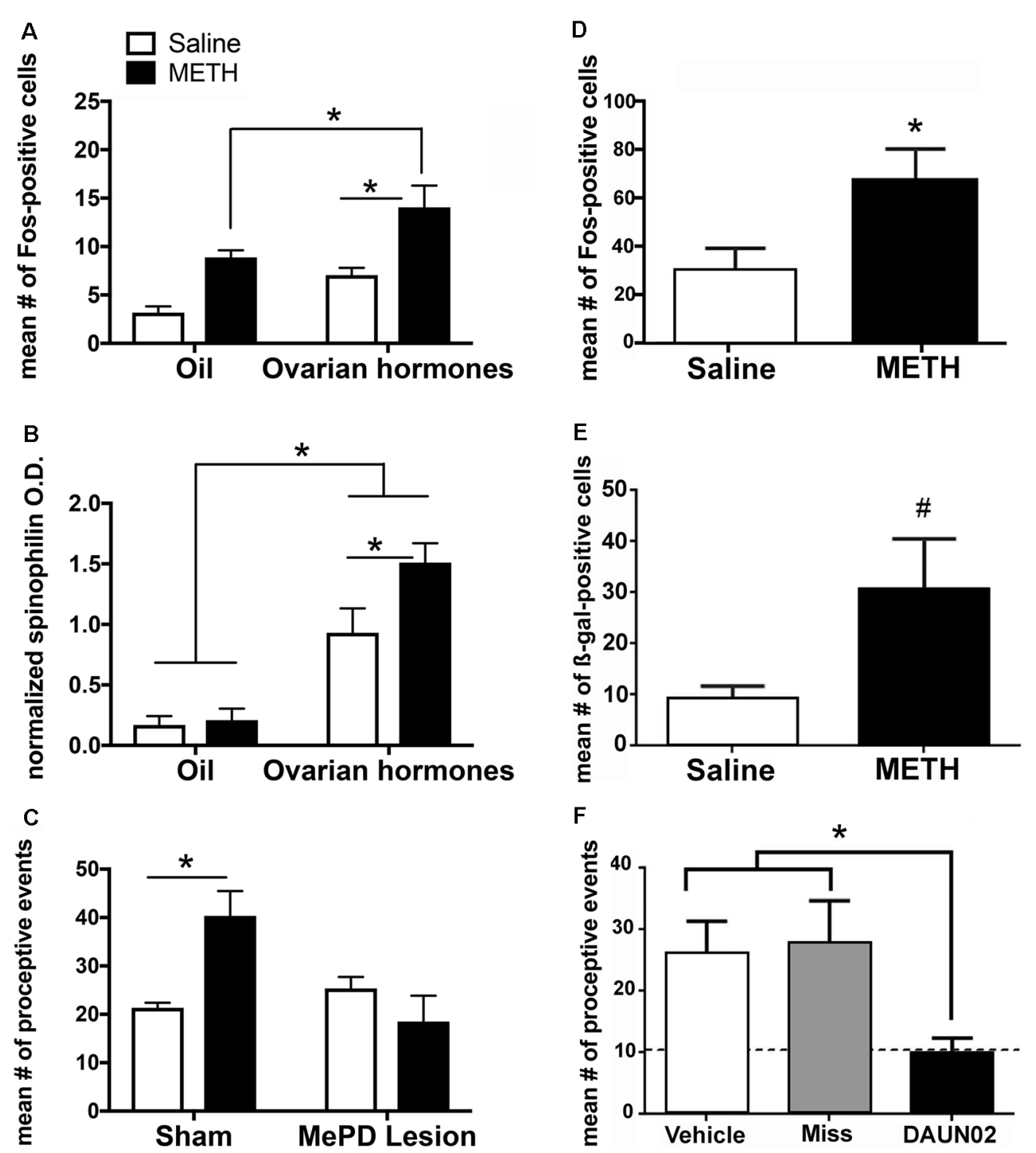

FIGURE 3 | The posterodorsal medial amygdala (MePD) is a locus for the enhancement of sexual motivation by METH. (A) The combination of METH and the ovarian hormones estradiol and progesterone increases Fos-immunoreactivity in the MePD, compared to either METH-oil controls and saline-hormone controls. (B) METH treatment significantly increases spinophilin protein levels, compared to saline-hormone controls. (C) There was a significant interaction of METH and the MePD lesion, such that the lesion of the MePD blocks the METH-induced increases in proceptive behaviors. (D) METH increases Fos-immunoreactivity in the presence of ovarian hormones in cFos-lacZ transgenic rats. (E) There is a strong trend towards an increase in $\beta$-galactocidase ( $\beta$-gal)-immunoreactivity in the presence of both ovarian hormones and METH in cFos-lacZ transgenic rats. (F) DAUNO2 inactivation of ovarian hormone- and METH-responsive cells in the MePD prevents the METH-induced increase in proceptive behavior, compared to vehicle-controls and animals in which DAUNO2 is infused into areas other than the MePD (Miss). The dashed line represents the baseline levels of proceptive behavior induced by ovarian hormones. Data represents means \pm SEM; ${ }^{*} p<0.05,{ }^{\#} p=0.05$. Reprinted with permission from Elsevier, Inc., Amsterdam, Netherlands; (A-C) and under the use of the Creative Commons license (D-F).

integral part of the chromatin around which the DNA spools, which lead to more global alteration of gene transcription (reviewed in Robison and Nestler, 2011). DNA methylation, in which methyl groups are added to DNA molecules by DNA methyltransferase (DNMT), results in repression of gene transcription. Both METH and ovarian hormones reduce the enzymatic activity of DNMT in the MePD (Rudzinskas and Mong, 2018). Acetylation of the histones enables gene transcription by allowing chromatin expansion, and histone deacetylases (HDAC) are enzymes that remove the acetyl groups, 
leading to more tightly coiled DNA and a reduction of gene transcription. The combination of both METH and ovarian hormones reduces the enzymatic activity of HDAC in the MePD (Rudzinskas and Mong, 2018). Reduced activity of both HDAC and DNMT should allow for enhanced gene transcription in cells of the MePD. Moreover, these data further support the notion that the MePD is a locus for this enhanced sexual motivation, as no significant changes in HDAC or DNMT activity occur in the VMN. In addition, these changes in enzymatic activity are not the result of changes in the total protein levels of the enzymes (Rudzinskas and Mong, 2018). Taken together, these data suggest that dynamic epigenetic changes may play some role in the genetic mechanisms which underlie METH-enhanced proceptivity. As such, these changes should be investigated further on a gene-by-gene basis, particularly in relationship to the genes explored in the next section of this review article.

\section{MECHANISMS OF ENHANCED SEXUAL MOTIVATION}

\section{Dopamine Receptors}

While cells within the MePD mediate the METH-facilitated increase in proceptive behavior, it remains unclear how METH and ovarian steroids specifically activate this cellular population to increase neural activation. One likely source of neural activation is dopamine, as one of the primary responses following METH administration is the release of a bolus of dopamine into the synapse (Sulzer et al., 2005; Fleckenstein et al., 2007). The $\mathrm{MePD}$ receives both direct and indirect inputs from the ventral tegmental area, a major source of dopaminergic synthesis in the mesolimbic, natural reward pathway (reviewed in Ikemoto, 2007). Thus, it is likely that dopamine receptor (DR) activation in the MePD mediates the enhanced sexually motivated behaviors by METH.

Activation of the excitatory D1-type DRs (D1Rs), which comprise both $D_{1} R$ and $D_{5} R$, in the MePD in the absence of METH increases the number of proceptive events above levels induced by ovarian hormones alone (Figure 4A). In addition, administration of an antagonist to these D1Rs in the MePD prevents the METH-induced increase in proceptive behaviors (Figure 4B; Holder et al., 2015). In contrast, administration of agonists or antagonists to the D2-type DRs, which comprise $D_{2} R, D_{3} R$ and $D_{4} R$, in the MePD has no effect on the number of proceptive behaviors displayed. Interestingly, the overall quantity of D1Rs in the MePD remained unchanged between treatment groups (Rudzinskas, 2017). These experiments suggest that METH, through a release of dopamine, may work through the activation of a stable population of D1Rs in the MePD to directly modify the expression of genes underlying female sexual motivation.

The DR agonists and antagonists were administered once a day, for 3 days; therefore, it is probable that the genes affected would be both those necessary for the immediate display of sexual motivation and behavior and those involved in more long-lasting changes to the sexual motivation circuit. One such gene whose expression could be modified via changes in D1R activation is the PR (Olesen et al., 2005, 2007). Indeed, METH alone, in the

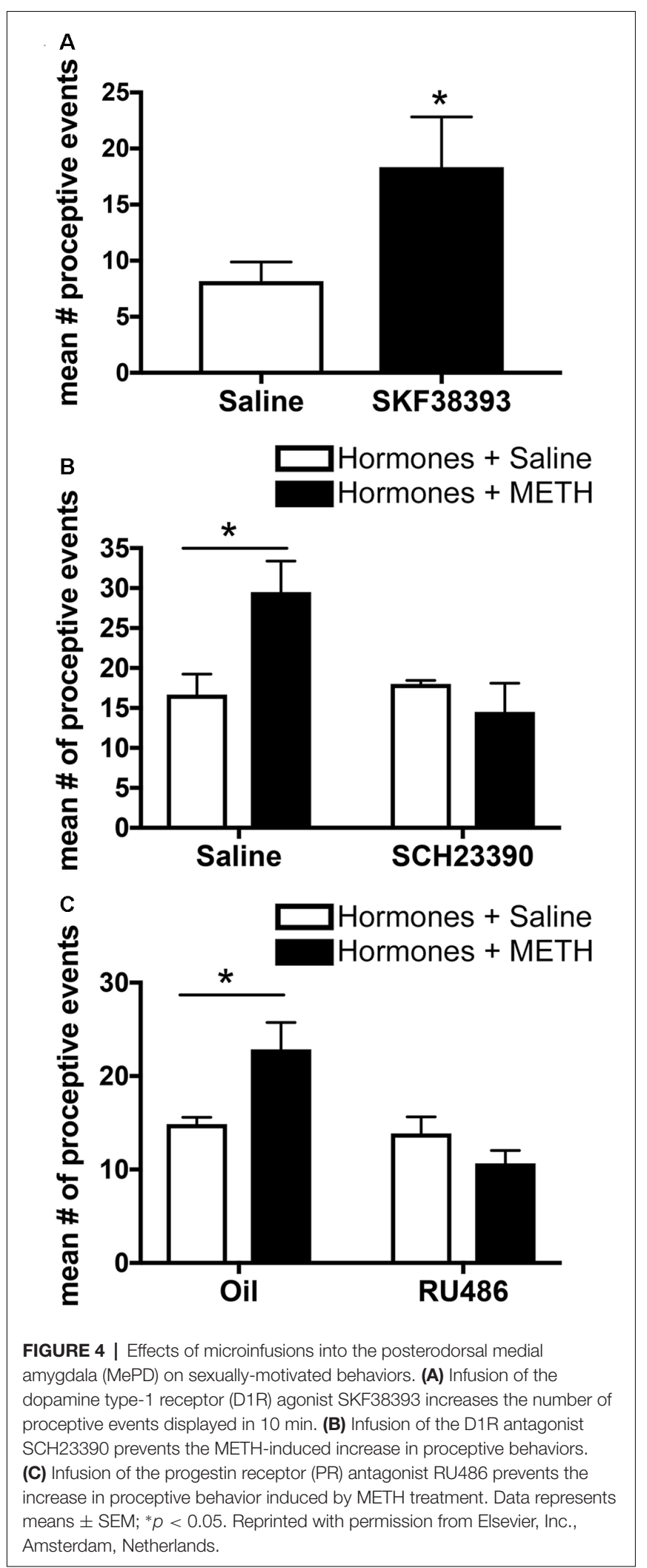

absence of estradiol, increases PRs in the MePD (Holder et al., 2015). However, in a follow-up study, a D1R antagonist infused into the MePD at the same time of METH administration failed 


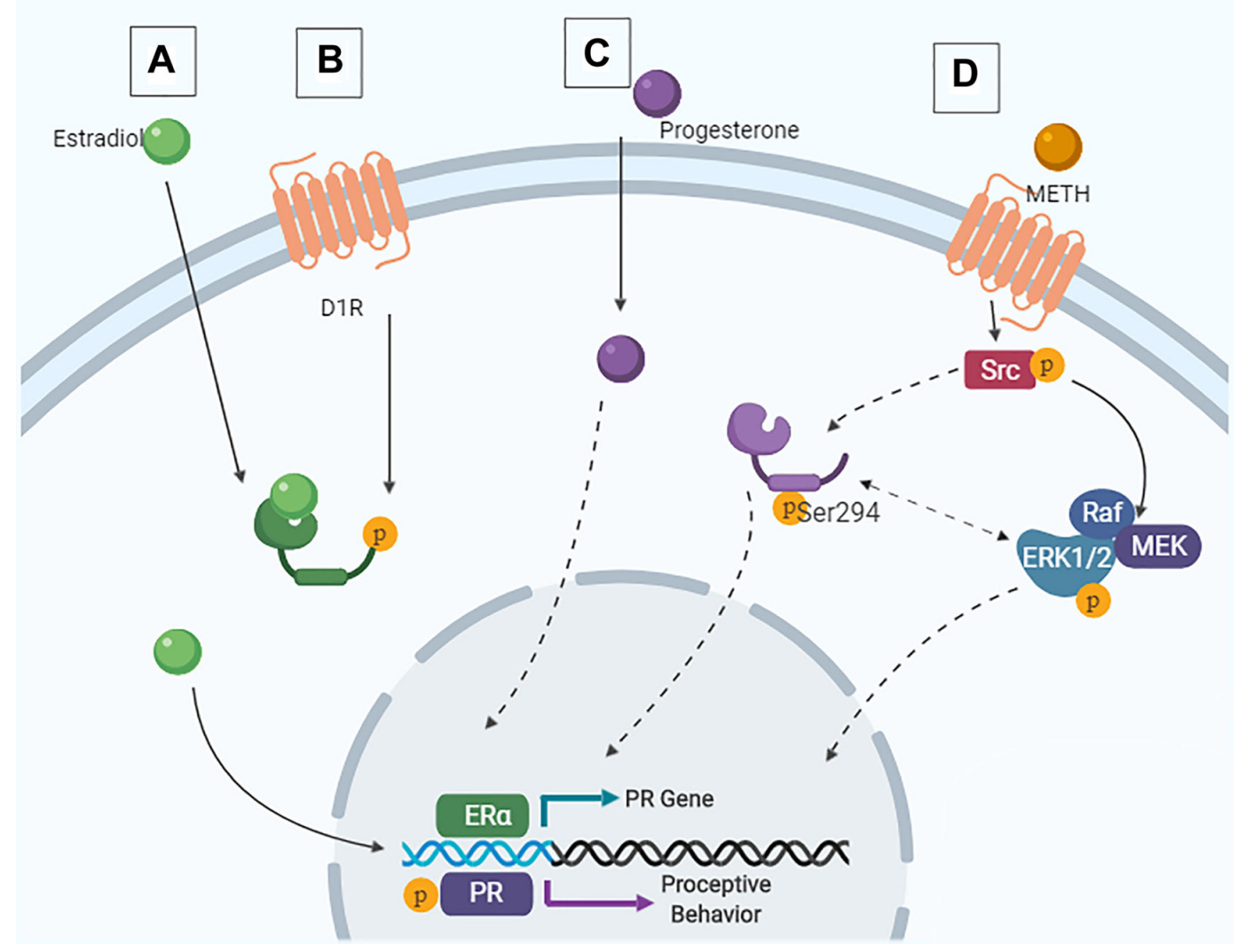

FIGURE 5 | Intracellular signaling cascades in the MePD that contribute to female sexual motivation. (A) Estradiol enters the cell and binds to estrogen receptor (ER), leading to ligand-dependent gene transcription. (B) Following METH-induced dopamine release, signaling via the D1R also leads to ER translocation to the nucleus and ligand-independent transcription of the PR. These are the priming stages. (C) Similarly, progesterone can enter the cell and lead to ligand-dependent signaling. (D) Following activation of the D1R, Src interacts with the PR, leading to phosphorylation of Src and PR at Ser294. This results in downstream ERK1/2 phosphorylation and increases proceptive behavior.

to change PR levels in the MePD (Williams et al., 2018). It may be microinfusions of the antagonist at a longer time course prior to METH administration may have prevented the METH-induced increase in PRs.

\section{Progesterone Receptors}

Progesterone and activation of the PRs are necessary for the display of proceptive behavior, and there is functional specificity of the two isoforms of the nuclear receptor. $\mathrm{PR}_{A}$ activation contributes primarily to the display of lordosis, whereas $P_{B}$ activation seems to contribute primarily to proceptivity (Mani et al., 2006). PR activation, primarily through $\mathrm{PR}_{\mathrm{B}}$, in the MePD may facilitate increases in proceptive and other sexuallymotivated behavior. While the contributions of the PR isoforms in the MePD to enhancement of sexual motivation by METH has not been determined, it has been demonstrated that the microinfusion of RU486, a PR antagonist, into the MePD decreases the METH-facilitated proceptive behaviors (Figure 4C; Holder et al., 2015). Finally, recent work demonstrates that increasing PR protein expression with a lentiviral overexpression vector injected into the MePD in the absence of METH increases proceptive behaviors and lordosis intensity, with no other noted effects on social, exploratory, or rejection behaviors (Williams et al., 2018). Taken together, it is clear that PRs in the MePD have functional relevance toward the induction of female sexual motivation.

\section{Intracellular Mechanisms}

In addition to activated D1R increasing the number of PRs in the absence of estradiol, D1R activation can also activate PRs in the absence of progesterone (Auger, 2001); therefore, METH-facilitated activation of D1R could work via other, intracellular mechanisms in conjunction with the increased PRs to enhance sexual motivation. The ligand-bound PR is necessary to modulate proceptive behaviors; however, METH can facilitate these proceptive behaviors even in the presence of subthreshold doses of progesterone (Figure 2A; Holder et al., 2010). Taken together, this evidence suggests that METH administration enhances PR sensitivity to ligand in the MePD (Weigel et al., 1995).

The changes to $\mathrm{PR}$ sensitivity and/or functionality may arise from post-translational modifications, which include 
phosphorylation, acetylation, sumoylation, and ubiquitination (Hagan et al., 2012). Of these, the phosphorylation is thought to be the primary regulator of $\mathrm{PR}$ actions, such that phosphorylation of specific sites on the PR enhances transcriptional activity (Denner et al., 1990; Bai et al., 1997; Weigel and Moore, 2007). In fact, activation of D1Rs leads to a sequence of kinase phosphorylation events, which could then modulate the activational state of the PRs (Auger, 2001). The PR is highly promiscuous, as it is able to dock onto activated mitogenactivated protein kinases, such as the extracellular signalregulated kinases (ERK1/2), Src kinases, and the ERs ( $\mathrm{Lu}$ and $\mathrm{Xu}$, 2006; Dressing et al., 2009). ERK1/2 has been reported to directly phosphorylate the progesterone receptor, while both ERK1/2 and Src kinase have been reported to act in a complex with both ERs and PRs (Migliaccio et al., 1998; Boonyaratanakornkit et al., 2001). The activation of these kinase cascades leads to enhancements of both receptive and proceptive behaviors (González-Flores et al., 2009, 2010; Lima-Hernández et al., 2012).

As the activation of both D1Rs and PRs in the MePD are necessary for the METH-induced enhancement of proceptive behaviors, it is likely that the behaviorally-relevant neurons contain both D1Rs and PRs and that the METH-induced enhancement of sexual motivation arises due to the activity of kinases. In support, METH administration leads to phosphorylation of the ubiquitous kinases ERK1/2 and cSrc in hormonally intact or primed rats (Hebert and O'Callaghan, 2000; Choe et al., 2002; Zhang et al., 2004; Pascoli et al., 2005; Williams et al., 2018). The cytosolic-dependent kinase pathways that could be induced by D1R activation converge with the hormone-dependent kinase pathways at two serine sites in the PRs, serine 294 and 345, suggesting a molecular mechanism through which METH may modulate PR activity (Figure 5).

The combined actions of METH and the ovarian hormones increased the phosphorylation of PR serine 294, but not serine 345, in the MePD. Moreover, the administration of a D1R antagonist prevented this increase in phosphorylation of the $\mathrm{PR}_{\mathrm{B}}$ at serine 294 (Williams et al., 2018), further supporting the role of the $\mathrm{PR}_{\mathrm{B}}$ isoform in the mediation of proceptive behaviors. The activity of the Src kinase to phosphorylate serine 294 of the PR is required for the enhancements of sexual motivation of $\mathrm{METH}$; however, blocking the activation of the ERK1/2 also prevents the METH-induced increases of proceptive behaviors without affecting the serine 294 phosphorylation. Taken together, these data provide evidence of a direct molecular interaction of $\mathrm{D} 1 \mathrm{R}$ and PR actions such that the intracellular signaling cascades initiated by D1R activation phosphorylate a site on the PRs in order to modulate the activational states of the PRs. Further studies are necessary to elucidate the role of serine 294 in the $\mathrm{MePD}$ and in the relative contributions of the different kinase activation pathways in the MePD on the enhancement of sexual motivation in the female rat. The utilization of modern tools such

\section{REFERENCES}

Afonso, V. M., Lehmann, H., Tse, M., Woehrling, A., and Pfaus, J. G. (2009). Estrogen and the neural mediation of female-male mounting in the rat. Behav. Neurosci. 123, 369-381. doi: 10.1037/a0014121 as CRISPR/Cas-9 may provide further insights into the specificity of this signaling cascade as it relates to female sexual motivation. Ultimately, though, the activation of phosphorylation kinases and enhanced activation of PR would lead to an increase in the transcription of PR-dependent genes. The gene targets of the activated PRs in the MePD that enhance female sexual motivation and influence the central motive state have yet to be determined.

\section{CONCLUSION}

One of the key components for sexual behavior is that of sexual motivation. We have presented one model system in which we can further study the motivational aspects of sexual behavior. The data presented in this review article indicates that sexual motivation arises from interactions of neurotransmitters and steroid hormones to change the central motive state. In addition, these interactions can be influenced by pharmacological agents, such as METH, to further increase the central motive state and drive the response to sexually-relevant stimuli. With the advent of technologies that enable us to examine and determine the nature of these interactions on epigenetic and molecular levels, we approach answers to such fundamental questions as the origins of sexual motivation. The use of the METH-model of enhanced sexually-motivated behaviors has already revealed complexities to an admittedly intricate and multifaceted system; however, this model also presents new avenues for research that may ultimately reveal the origins of sexual desire.

\section{AUTHOR CONTRIBUTIONS}

SR, KW, JM, and MH designed the studies referenced. SR, $\mathrm{KW}$, and $\mathrm{MH}$ performed the experiments and wrote sections of the manuscript. $\mathrm{MH}$ wrote the outline of the manuscript. All authors contributed to manuscript revision, read and approved the submitted version.

\section{FUNDING}

This research was supported by National Institutes of Health (NIH) grant DA024943 awarded to $\mathrm{MH}$ and by NIH grant DA030517 awarded to JM. NIDA played no role in the study design, in the collection, analysis, and interpretation of data, in the writing of the report and in the decision to submit the paper for publication.

\section{ACKNOWLEDGMENTS}

We would like to thank Shaun Viechweg for his contributions for the microinfusion experiments and the maintenance and genotyping of the LacZ colony.

Ågmo, A. (1999). Sexual motivation-an inquiry into events determining the occurrence of sexual behavior. Behav. Brain Res. 105, 129-150. doi: 10.1016/s0166-4328(99)00088-1

Ågmo, A. (2007). Functional and Dysfunctional Sexual Behavior, 1st Edn. New York, NY: Elsevier Ltd. 
Auger, A. P. (2001). Ligand-independent activation of progestin receptors: relevance for female sexual behavior. Reproduction 122, 847-855. doi: 10.1530/reprod/122.6.847

Bai, W., Rowan, B. G., Allgood, V. E., O’Malley, B. W., and Weigel, N. L. (1997). Differential phosphorylation of chicken progesterone receptor in hormonedependent and ligand-independent activation. J. Biol. Chem. 272, 10457-10463. doi: $10.1074 /$ jbc.272.16.10457

Beach, F. A. (1942). Analysis of the stimuli adequate to elicit mating behavior in the sexually inexperience male rats. J. Comp. Psychol. 33, 163-207. doi: $10.1037 / \mathrm{h} 0061692$

Beach, F. A. (1976). Sexual attractivity, proceptivity, and receptivity in female mammals. Horm. Behav. 7, 105-138. doi: 10.1016/0018-506x(76)90008-8

Beach, F. A., Etkin, W., and Rasquin, P. (1942). Importance of progesterone to induction of sexual receptivity in spayed female rats. Exp. Biol. Med. 51, 369-371. doi: 10.3181/00379727-51-13979

Bergheim, D., Chu, X., and Ågmo, A. (2015). The function and meaning of female rat paracopulatory (proceptive) behaviors. Behav. Processes 118, 34-41. doi: 10.1016/j.beproc.2015.05.011

Bermant, G. (1961). Response latencies of female rats during sexual intercourse. Science 133, 177-1773. doi: 10.1126/science.133.3466.1771

Berridge, K. C. (2004). Motivation concepts in behavioral neuroscience. Physiol. Behav. 81, 179-209. doi: 10.1016/j.physbeh.2004.02.004

Berridge, K. C. (2007). The debate over dopamine's role in reward: the case for incentive salience. Psychopharmacology 191, 391-431. doi: 10.1007/s00213006-0578-x

Berridge, K. C. (2019). Affective valence in the brain: modules or modes? Nat. Rev. Neurosci. 20, 225-234. doi: 10.1038/s41583-019-0122-8

Bindra, D. (1974). A motivational view of learning, performance, and behavior modification. Psychol. Rev. 81, 199-213. doi: 10.1037/h0036330

Blaustein, J. D. (2008). Neuroendocrine regulation of feminine sexual behavior: lessons from rodent models and thoughts about humans. Ann. Rev. Psychol. 59, 93-118. doi: 10.1146/annurev.psych.59.103006.093556

Boling, J. L., and Blandau, R. J. (1939). The estrogen-progesterone induction of mating responses in the spayed female rat. Endocrinology 25, 359-364. doi: 10.1210/endo-25-3-359

Boonyaratanakornkit, V., Scott, M. P., Ribon, V., Sherman, L., Anderson, S. M., Maller, J. L., et al. (2001). Progesterone receptor contains a proline-rich motif that directly interacts with $\mathrm{SH} 3$ domains and activates c-Src family tyrosine kinases. Mol. Cell 8, 269-280. doi: 10.1016/s1097-2765(01)00304-5

Brink, E. E., and Pfaff, D. W. (1980). Vertebral muscles of the back and tail of the albino rat (Rattus norvegicus albinus). Brain Behav. Evol. 17, 1-47. doi: $10.1159 / 000121789$

Choe, E. S., Chung, K. T., Mao, L., and Wang, J. Q. (2002). Amphetamine increases phosphorylation of extracellular signal-regulated kinase and transcription factors in the rat striatum via group I metabotropic glutamate receptors. Neuropsychopharmacology 27, 565-575. doi: 10.1016/s0893-133x(02)00341-x

Chu, X., and Ågmo, A. (2014). Sociosexual behaviours in cycling, intact female rats (Rattus norvegicus) housed in a seminatural environment. Behaviour 151, 1143-1184. doi: 10.1163/1568539x-00003177

Chu, X., and Ågmo, A. (2015). Sociosexual behaviors during the transition from non-receptivity to receptivity in rats housed in a seminatural environment. Behav. Processes 113, 24-34. doi: 10.1016/j.beproc.2015.01.001

Chu, H.-P., and Etgen, A. M. (1999). Ovarian hormone dependence of $\alpha_{1}$-adrenoceptor activation of the nitric oxide-cGMP pathway: revelance for hormonal facilitation of lordosis behavior. J. Neurosci. 19, 7191-7197. doi: 10.1523/JNEUROSCI.19-16-07191.1999

Chu, X., Gagnidze, K., Pfaff, D., and Ågmo, A. (2015). Estrogens, androgens and generalized behavioral arousal in gonadectomized female and male C57BL/6 mice. Physiol. Behav. 147, 255-263. doi: 10.1016/j.physbeh.2015. 04.053

Chu, H.-P., Morales, J. C., and Etgen, A. M. (1999). Cyclic GMP may potentiate lordosis behaviour by progesterone receptor activation. J. Neuroendocrinol. 11, 107-113. doi: 10.1046/j.1365-2826.1999.00298.x

Cummings, J. A., and Becker, J. B. (2012). Quantitative assessment of female sexual motivation in the rat: hormonal control of motivation. J. Neurosci. Methods 204, 227-233. doi: 10.1016/j.jneumeth.2011.11.017

Daniels, D., Miselis, R. R., and Flanagan-Cato, L. M. (1999). Central neuronal circuit innervating the lordosis-producing muscles defined by transneuronal transport of pseudorabies virus. J. Neurosci. 19, 2823-2833. doi: 10.1523/JNEUROSCI.19-07-02823.1999

Davis, P. G., McEwen, B. S., and Pfaff, D. W. (1979). Localized behavioral effects of tritiated estradiol implants in the ventromedial hypothalamus of female rats. Endocrinology 104, 898-903. doi: 10.1210/endo-104-4-898

Denner, L. A., Weigel, N. L., Maxwell, B. L., Schader, W. T., and O'Malley, B. W. (1990). Regulation of progesterone receptor-mediated transcription by phosphorylation. Science 250, 1740-1743. doi: 10.1126/science. 2176746

Dressing, G. E., Hagan, C. R., Knutson, T. P., Daniel, A. R., and Lange, C. A. (2009). Progesterone receptors act as sensors for mitogenic protein kinases in breast cancer models. Endocr. Relat. Cancer 16, 351-361. doi: 10.1677/erc-08-0281

Drewett, R. F., and Spiteri, N. J. (1979). The sexual attractiveness of male rats: olfactory and behavioral components. Physiol. Behav. 23, 207-209. doi: 10.1016/0031-9384(79)90146-x

Edwards, D. A., and Pfeifle, J. K. (1983). Hormonal control of receptivity, proceptivity and sexual motivation. Physiol. Behav. 30, 437-443. doi: 10.1016/0031-9384(83)90150-6

Erskine, M. S. (1985). Effects of paced coital stimulation on estrus duration in intact cycling rats and ovariectomized and ovariectomized-adrenalectomized hormone-primed rats. Behav. Neurosci. 99, 151-161. doi: 10.1037/0735-7044. 99.1.151

Erskine, M. S. (1989). Solicitation behavior in the estrous female rat: a review. Horm. Behav. 23, 473-502. doi: 10.1016/0018-506x(89)90037-8

Erskine, M. S., and Baum, M. J. (1982). Effects of paced coital stimulation on termination of estrus and brain indoleamine levels in female rats. Pharmacol. Biochem. Behav. 17, 857-861. doi: 10.1016/0091-3057(82)90373-2

Fadem, B. H., Barfield, R. J., and Whalen, R. E. (1979). Dose-response and time-response relationships between progesterone and the display of patterns of receptive and proceptive behavior in the female rat. Horm. Behav. 13, 40-48. doi: 10.1016/0018-506x(79)90033-3

Fahrbach, S. E., Morrell, J. I., and Pfaff, D. W. (1989). Studies of ventromedial hypothalamic afferents in the rat using three methods of HRP application. Exp. Brain Res. 77, 221-233. doi: 10.1007/bf00274980

Farquhar, D., Pan, B. F., Sakurai, M., Ghosh, A., Mullen, C. A., and Nelson, J. A. (2002). Suicide gene therapy using E. coli $\beta$-galactosidase. Cancer Chemother. Pharmacol. 50, 65-70. doi: 10.1007/s00280-002-0438-2

Femano, P. A., Schwartz-Giblin, S., and Pfaff, D. W. (1984a). Brain stem reticular influences on lumbar axial muscle activity: I. Effective sites. Am. J. Physiol. 246, R389-R395. doi: 10.1152/ajpregu.1984.246.3.r389

Femano, P. A., Schwartz-Giblin, S., and Pfaff, D. W. (1984b). Brain stem reticular influences on lumbar axial muscle activity: II. Temporal aspects. Am. J. Physiol. 246, R396-R401. doi: 10.1152/ajpregu.1984.246.3.r396

Fernández-Guasti, A., Ahlenius, S., Hjorth, S., and Larsson, K. (1987). Separation of dopaminergic and serotonergic inhibitory mechanisms in the mediation of estrogen-induced lordosis behavior in the rat. Pharmacol. Biochem. Behav. 27, 93-98. doi: 10.1016/0091-3057(87)90482-5

Fernández-Guasti, A., Larsson, K., and Beyer, C. (1985a). Potentiative action of $\alpha$ - and $\beta$-adrenergic receptor stimulation in inducing lordosis behavior. Pharmacol. Biochem. Behav. 22, 613-617. doi: 10.1016/0091-3057(85) 90283-7

Fernández-Guasti, A., Larsson, K., and Beyer, C. (1985b). Prevention of progesterone-induced lordosis behavior by $\alpha$ or $\beta$ adrenergic antagonists in ovariectomized estrogen-primed rats. Pharmacol. Biochem. Behav. 22, 279-282. doi: 10.1016/0091-3057(85)90391-0

Flanagan, L. M., Pfaus, J. G., Pfaff, D. W., and McEwen, B. S. (1993). Induction of FOS immunoreactivity in oxytocin neurons after sexual activity in female rats. Neuroendocrinology 58, 352-358. doi: 10.1159/000126562

Flanagan-Cato, L. M., and McEwen, B. S. (1995). Pattern of Fos and Jun expression in the female rat forebrain after sexual behavior. Brain Res. 673, 53-60. doi: 10.1016/0006-8993(94)01395-x

Fleckenstein, A. E., Volz, T. J., Riddle, E. L., Gibb, J. W., and Hanson, G. R. (2007). New insights into the mechanism of action of amphetamines. Annu. Rev. Pharmacol. Toxicol. 47, 681-698. doi: 10.1146/annurev.pharmtox.47.120505. 105140

Foreman, M. M., and Moss, R. L. (1979). Role of hypothalamic dopaminergic receptors in the control of lordosis behavior in the female rat. Physiol. Behav. 22, 283-289. doi: 10.1016/0031-9384(79)90088-x 
Freeman, M. (1994). "The neuroendocrine control of the ovarian cycle of the rat," in The Physiology of Reproduction, 2nd Edn., eds E. Knobil and J. Neill (New York, NY: Raven), 613.

French, D., Fitzpatrick, D., and Law, O. T. (1972). Operant investigation of mating preferences in female rats. J. Comp. Physiol. Psychol. 81, 226-232. doi: $10.1037 / \mathrm{h} 0033535$

Galtress, T., Marshall, A. T., and Kirkpatrick, K. (2012). Motivation and timing: clues for modeling the reward system. Behav. Processes 90, 142-153. doi: 10.1016/j.beproc.2012.02.014

García-Horsman, S. P., Ågmo, A., and Paredes, R. G. (2008). Infusions of naloxone into the medial preoptic area, ventromedial nucleus of the hypothalamus, and amygdala block conditioned place preference induced by paced mating behavior. Horm. Behav. 54, 709-716. doi: 10.1016/j.yhbeh.2008.07.011

González-Flores, O., Beyer, C., Gómora-Arrati, P., García-Juárez, M., LimaHernández, F. J., Soto-Sánchez, A., et al. (2010). A role for Src kinase in progestin facilitation of estrous behavior in estradiol-primed female rats. Horm. Behav. 58, 223-229. doi: 10.1016/j.yhbeh.2010.03.014

González-Flores, O., Gómora-Arrati, P., Garcia-Juárez, M., GómezCamarillo, M. A., Lima-Hernández, F. J., Beyer, C., et al. (2009). Nitric oxide and ERK/MAPK mediation of estrous behavior induced by $\mathrm{GnRH}$, PGE2 and db-cAMP in rats. Physiol. Behav. 96, 606-612. doi: 10.1016/j. physbeh.2008.12.019

Gray, T. S. (1999). Functional and anatomical relationships among the amygdala, basal forebrain, ventral striatum, and cortex. An integrative discussion. Ann. N Y Acad. Sci. 877, 439-444. doi: 10.1111/j.1749-6632.1999.tb09281.x

Grierson, J. P., James, M. D., Pearson, J. R., and Wilson, C. A. (1988). The effect of selective $D_{1}$ and $D_{2}$ dopaminergic agents on sexual receptivity in the female rat. Neuropharmacology 2, 181-189. doi: 10.1016/0028-3908(88)90169-4

Guarraci, F. A. (2010). "Sex, drugs and the brain": the interaction between drugs of abuse and sexual behavior in the female rat. Horm. Behav. 58, 138-148. doi: 10.1016/j.yhbeh.2009.12.002

Hagan, C. R., Daniel, A. R., Dressing, G. E., and Lange, C. A. (2012). Role of phosphorylation in progesterone receptor signaling and specificity. Mol. Cell. Endocrinol. 357, 43-49. doi: 10.1016/j.mce.2011.09.017

Haile, C. N., Kosten, T. R., and Kosten, T. A. (2009). Pharmacogenetic treatments for drug addiction: cocaine, amphetamine and methamphetamine. Am. J. Drug Alcohol Abuse 35, 161-177. doi: 10.1080/00952990902825447

Hebert, M. A., and O'Callaghan, J. P. (2000). Protein phosphorylation cascades associated with methamphetamine-induced glial activation. Ann. N Y Acad. Sci. 914, 238-262. doi: 10.1111/j.1749-6632.2000.tb05200.x

Hemmingsen, A. M. (1933). Studies on the oestrus-producing hormone (oestrin). Skand. Arch. Physiol. 65, 97-250. doi: 10.1111/j.1748-1716.1933.tb00348.x

Holder, M. K., Hadjimarkou, M. M., Zup, S. L., Blutstein, T., Benham, R. S., McCarthy, M. M., et al. (2010). Methamphetamine facilitates female sexual behavior and enhances neuronal activation in the medial amygdala and ventromedial nucleus of the hypothalamus. Psychoneuroendocrinology 35, 197-208. doi: 10.1016/j.psyneuen.2009.06.005

Holder, M. K., and Mong, J. A. (2010). Methamphetamine enhances paced mating behaviors and neuroplasticity in the medial amygdala of female rats. Horm. Behav. 58, 519-525. doi: 10.1016/j.yhbeh.2010.04.006

Holder, M. K., and Mong, J. A. (2017). The role of ovarian hormones and the medial amygdala in sexual motivation. Curr. Sex. Health Rep. 9, 262-270. doi: 10.1007/s11930-017-0131-4

Holder, M. K., Veichweg, S. S., and Mong, J. A. (2015). Methamphetamineenhanced female sexual motivation is dependent on dopamine and progesterone signaling in the medial amygdala. Horm. Behav. 67, 1-11. doi: 10.1016/j.yhbeh.2014.10.004

Ikemoto, S. (2007). Dopamine reward circuitry: two projection systems from the ventral midbrain to the nucleus accumbens-olfactory tubercle complex. Brain Res. Rev. 56, 27-78. doi: 10.1016/j.brainresrev.2007.05.004

Jenkins, W. J., and Becker, J. B. (2003a). Dynamic increases in dopamine during paced copulatioin in the female rat. Eur. J. Neurosci. 18, 1997-2001. doi: 10.1046/j.1460-9568.2003.02923.x

Jenkins, W. J., and Becker, J. B. (2003b). Female rats develop conditioned place preferences for sex at their preferred interval. Horm. Behav. 43, 503-507. doi: 10.1016/s0018-506x(03)00031-x

Keller, M., Baum, M. J., Brock, O., Brennan, P. A., and Bakker, J. (2009). The main and the accessory olfactory systems interact in the control of mate recognition and sexual behavior. Behav. Brain Res. 200, 268-276. doi: 10.1016/j.bbr.2009. 01.020

Kevetter, G. A., and Winans, S. S. (1981). Connections of the corticomedial amygdala in the golden hamster: I. Efferents of the "vomeronasal amygdala". J. Comp. Neurol. 197, 81-98. doi: 10.1002/cne.901970107

Kondo, Y., and Sakuma, Y. (2005). The medial amygdala controls the coital access of female rats: a possible involvement of emotional responsiveness. J. Physiol. 55, 345-353. doi: 10.2170/jjphysiol.RP001105

Kow, L. M., Harlan, R. E., Shivers, B. D., and Pfaff, D. W. (1985). Inhibition of the lordosis reflex in rats by intrahypothalamic infusion of neural excitatory agents: evidence that the hypothalamus contains separate inhibitory and facilitatory elements. Brain Res. 341, 26-34. doi: 10.1016/0006-8993(85)91468-4

Koya, E., Margetts-Smith, G., and Hope, B. T. (2016). Daun02 inactivation of behaviorally activated fos-expressing neuronal ensembles. Curr. Protoc. Neurosci. 76, 8.36.1-8.36.17. doi: 10.1002/cpns.2

Lima-Hernández, F. J., Beyer, C., Gomora-Arrati, P., Garcia-Juarez, M., Encarnacion-Sanchez, J. L., Etgen, A. M., et al. (2012). Src kinase signaling mediates estrous behavior induced by $5 \beta$-reduced progestins, GnRH, prostaglandin E2 and vaginocervical stimulation in estrogen-primed rats. Horm. Behav. 62, 579-584. doi: 10.1016/j.yhbeh.2012.09.004

Lorvick, J., Bourgois, P., Wenger, L. D., Arreola, S. G., Lutnick, A., Wechsberg, W. M., et al. (2012). Sexual pleasure and sexual risk among women who use methamphetamine: a mixed methods study. Int. J. Drug Policy 23, 385-392. doi: 10.1016/j.drugpo.2012.07.005

Lovell, J. L., Diehl, A., Joyce, E., Cohn, J., Lopez, J., and Guarraci, F. A. (2007). "Some guys have all the luck": mate preference influences paced-mating behavior in female rats. Physiol. Behav. 90, 537-544. doi: 10.1016/j.physbeh. 2006.11.002

Lu, Z., and Xu, S. (2006). ERK1/2 MAP kinases in cell survival and apoptosis. IUBMB Life 58, 621-631. doi: 10.1080/15216540600957438

Madlafousek, J., and Hliňák, Z. (1977). Sexual behavior of the female laboratory rat: inventory, patterning, and measurement. Behaviour 63, 129-173. doi: 10.1163/156853977x00397

Madlafousek, J., and Hliňák, Z. (1983). Importance of female's precopulatory behavior in the primary initiation of male's copulatory behaviour in the laboratory rat. Behaviour 86, 237-248. doi: 10.1163/156853983x00381

Mani, S. K., Reyna, A. M., Chen, J. Z., Mulac-Jericevic, B., and Conneely, O. M. (2006). Differential response of progesterone receptor isoforms in hormonedependent and -independent facilitation of female sexual receptivity. Mol. Endocrinol. 20, 1322-1332. doi: 10.1210/me.2005-0466

Mansergh, G., Purcell, D. M., Stall, R., McFarlane, M., Semann, S., Valentine, J., et al. (2006). CDC consultation on methamphetamine use and sexual risk behavior for HIV/STD infection: summary and suggestions. Public Health Rep. 121, 127-132. doi: 10.1177/003335490612100205

Mascó, D. H., and Carrer, H. F. (1980). Sexual receptivity in female rats after lesion or stimulation in different amygdaloid nuclei. Physiol. Behav. 24, 1073-1080. doi: 10.1016/0031-9384(80)90050-5

Mascó, D. H., and Carrer, H. F. (1984). Pathways conducting amygdaloid influence on feminine sexual behavior in the rat. Behav. Brain Res. 11, 205-212. doi: 10.1016/0166-4328(84)90212-2

Mathews, D., and Edwards, D. A. (1977). Involvement of the ventromedial and anterior hypothalamic nuclei in the hormonal induction of receptivity in the female rat. Physiol. Behav. 19, 319-326. doi: 10.1016/0031-9384(77)90345-6

Matthews, T. J., Grigore, M., Tang, L., Doat, M., Kow, L. M., and Pfaff, D. W. (1997). Sexual reinforcement in the female rat. J. Exp. Anal. Behav. 68, 399-410. doi: 10.1901/jeab.1997.68-399

McClintock, M. K., and Adler, N. T. (1978). The role of the female during copulation in wild and domestic Norway rats (Rattus norvegicus). Behaviour 67, 67-95. doi: 10.1163/156853978x00260

Meerts, S. H., and Clark, A. S. (2007). Female rats exhibit a conditioned place preference for nonpaced mating. Horm. Behav. 51, 89-94. doi: 10.1016/j.yhbeh. 2006.08.007

Meyerson, B. J., and Lindström, L. H. (1973). Sexual motivation in the female rat. Acta Physiol. Scand. Suppl. 389, 1-80.

Migliaccio, A., Piccolo, D., Castoria, G., Di Domenico, M., Bilancio, A., Lombardi, M., et al. (1998). Activation of the Src/p21ras/Erk pathway by progesterone receptor via cross-talk with estrogen receptor. EMBO J. 17, 2008-2018. doi: 10.1093/emboj/17.7.2008 
Moss, R. L., Paloutzian, R. F., and Law, O. T. (1974). Electrical stimulation of forebrain structures and its effect on copulatory as well as stimulusbound behavior in ovariectomized hormone-primed rats. Physiol. Behav. 12, 997-1004. doi: 10.1016/0031-9384(74)90147-4

Nequin, L. G., Alvarez, J., and Schwartz, N. B. (1979). Measurement of serum steroid and gonadotropin levels and uterine and ovarian variables throughout 4 day and 5 day estrous cycles in the rat. Biol. Reprod. 20, 659-670. doi: 10.1095/biolreprod20.3.659

Olesen, K. M., Auger, C. J., and Auger, A. P. (2007). Regulation of progestin receptor expression in the developing rat brain by a dopamine $\mathrm{d} 1$ receptor antagonist. J. Neuroendocrinol. 19, 481-488. doi: 10.1111/j.1365-2826.2007. 01554.x

Olesen, K. M., Jessen, H. M., Auger, C. J., and Auger, A. P. (2005). Dopaminergic activation of estrogen receptors in neonatal brain alters progestin receptor expression and juvenile social play behavior. Endocrinology 146, 3705-3712. doi: 10.1210/en.2005-0498

Olster, D. H., and Blaustein, J. D. (1988). Progesterone facilitation of lordosis in male and female Sprague-Dawley rats following priming with estradiol pulses. Horm. Behav. 22, 294-304. doi: 10.1016/0018-506x(88) 90002-5

Orsulak, P. J., and Gawienowski, A. M. (1972). Olfactory preferences for the rat preputial gland. Biol. Reprod. 6, 219-223. doi: 10.1093/biolreprod/6.2.219

Paredes, R. G., and Alonso, A. (1997). Sexual behavior regulated (paced) by the female induces conditioned place preference. Behav. Neurosci. 111, 123-128. doi: 10.1037/0735-7044.111.1.123

Pascoli, V., Valjent, E., Corbille, A. G., Corvol, J. C., Tassin, J. P., Girault, J. A., et al. (2005). cAMP and extracellular signal-regulated kinase signaling in response to $\mathrm{d}$-amphetamine and methylphenidate in the prefrontal cortex in vivo: role of $\beta 1$-adrenoceptors. Mol. Pharmacol. 68, 421-429. doi: 10.1124/mol.105. 011809

Petitti, N., and Etgen, A. M. (1990). a 1-adrenoceptor augmentation of $\beta$-stimulated cAMP formation is enhanced by estrogen and reduced by progesterone in rat hypothalamic slices. J. Neurosci. 10, 2842-2849. doi: 10.1523/jneurosci.10-08-02842.1990

Pfaff, D., and Keiner, M. (1973). Atlas of estradiol-concentrating cells in the central nervous system of the female rat. J. Comp. Neurol. 151, 121-158. doi: 10.1002/cne.901510204

Pfaff, D., Ribeiro, A., Matthews, J., and Kow, L. M. (2008). Concepts and mechanisms of generalized central nervous system arousal. Ann. N Y Acad. Sci. 1129, 11-25. doi: 10.1196/annals.1417.019

Pfaff, D. W. (1999). Drive: Neural and Molecular Mechanisms for Sexual Motivation. Cambridge, MA: MIT Press.

Pfaff, D. W., and Sakuma, Y. (1979). Facilitation of the lordosis reflex of female rats from the ventromedial nucleus of the hypothalamus. J. Physiol. 288, 189-202.

Pfarr, S., Meinhardt, M. W., Klee, M. L., Hansson, A. C., Vengeliene, V., Schonig, K., et al. (2015). Losing control: excessive alcohol seeking after selective inactivation of cue-responsive neurons in the infralimbic cortex. J. Neurosci. 35, 10750-10761. doi: 10.1523/JNEUROSCI.0684-15.2015

Pfaff, D. W., Schwartz-Giblin, S., McCarthy, M. M., and Kow, L. (1994). "Cellular and molecular mechanisms of female reproductive behaviors," in The Physiology of Reproduction, eds E. Knobil, J. D. Neill, G. S. Greenwald, C. L. Markert and D. W. Pfaff (New York, NY: Raven), 107-197.

Pfaus, J. G., and Heeb, M. (1997). Implications of immediate-early gene induction in the brain following sexual stimulation of female and male rodents. Brain Res. Bull. 44, 397-407. doi: 10.1016/s0361-9230(97)00219-0

Pfaus, J. G., Kippin, T. E., and Coria-Avila, G. (2003). What can animal models tell us about human sexual response? Annu. Rev. Sex Res. 14, 1-63. doi: 10.1080/10532528.2003.10559810

Pfaus, J. G., Marcangione, C., Smith, W. J., Manitt, C., and Abillamaa, H. (1996). Differential induction of fos in the female rat brain following different amounts of vaginocervical stimulation: modulation by steroid hormones. Brain Res. 741, 314-330. doi: 10.1016/s0006-8993(96)00985-7

Pfaus, J. G., Scardochio, T., Parada, M., Gerson, C., Quintana, G. R., and CoriaAvila, G. A. (2016). Do rats have orgasms? Socioaffect. Neurosci. Psychol. 6:31883. doi: $10.3402 /$ snp.v6.31883

Pitkänen, A. (2000). "Connectivity of the rat amygdaloid complex," in The Amygdala, 2nd Edn., ed. J. P. Aggleton (New York, NY: Oxford University Press), 31-115.
Polston, E. K., and Erskine, M. S. (1995). Patterns of induction of the immediate-early genes c-fos and egr- 1 in the female rat brain following differential amounts of mating stimulation. Neuroendocrinology 62, 370-384. doi: $10.1159 / 000127027$

Powers, B., and Valenstein, E. S. (1972). Sexual receptivity: facilitation by medial preoptic lesions in female rats. Science 175, 1003-1005. doi: 10.1126/science. 175.4025.1003

Rawson, R. A., Washton, A., Domier, C. P., and Reiber, C. (2002). Drugs and sexual effects: role of drug type and gender. J. Subst. Abuse Treat. 22, 103-108. doi: 10.1016/s0740-5472(01)00215-x

Robison, A. J., and Nestler, E. J. (2011). Transcriptional and epigenetic mechanisms of addiction. Nat. Rev. Neurosci. 12, 623-637. doi: $10.1038 / \mathrm{nrn} 3111$

Rudzinskas, S. A. (2017). Stimulus specificity and the roles of progesterone and dopamine receptors in a model of methamphetamine-facilitated female sexual motivation. Baltimore: University of Maryland. Available online at: UMB Digital Archive, https://hdl.handle.net/10713/6711. Assessed June 19, 2019

Rudzinskas, S. A., and Mong, J. A. (2016). Androgen-primed castrate males are sufficient for methamphetamine-facilitated increases in proceptive behavior in female rats. Horm. Behav. 78, 52-59. doi: 10.1016/j.yhbeh.2015. 10.008

Rudzinskas, S. A., and Mong, J. A. (2018). Methamphetamine alters DNMT and HDAC activity in the posterior dorsal medial amygdala in an ovarian steroiddependent manner. Neurosci. Lett. 683, 125-130. doi: 10.1016/j.neulet.2018. 06.042

Sakuma, Y., and Pfaff, D. W. (1979). Facilitation of female reproductive behavior from mesensephalic central gray in the rat. Am. J. Physiol. 237, R278-R284. doi: 10.1152/ajpregu.1979.237.5.r278

Santone, K. S., Oakes, S. G., Taylor, S. R., and Powis, G. (1986). Anthracyclineinduced inhibition of a calcium action potential in differentiated murine neuroblastoma cells. Cancer Res. 46, 2659-2664.

Schwartz-Giblin, S., and Pfaff, D. W. (1980). Implanted strain gauge and EMG amplifier to record motor behavior in unrestrained rats. Physiol. Behav. 25, 475-479. doi: 10.1016/0031-9384(80)90291-7

Semple, S. J., Grant, I., and Patterson, T. L. (2004a). Female methamphetamine users: social characteristics and sexual risk behavior. Women Health 40, 35-50. doi: 10.1300/j013v40n03_03

Semple, S. J., Patterson, T. L., and Grant, I. (2004b). The context of sexual risk behavior among heterosexual methamphetamine users. Addict. Behav. 29, 807-810. doi: 10.1016/j.addbeh.2004.02.013

Simerly, R. B. (2002). Wired for reproduction: organization and development of sexually dimorphic circuits in the mammalian forebrain. Annu. Rev. Neurosci. 25, 507-536. doi: 10.1146/annurev.neuro.25.112701.142745

Simerly, R. B., Chang, C., Muramatsu, M., and Swanson, L. W. (1990). Distribution of androgen and estrogen receptor mRNA-containing cells in the rat brain: an in situ hybridization study. J. Comp. Neurol. 294, 76-95. doi: 10.1002/cne. 902940107

Spiteri, T., Musatov, S., Ogawa, S., Ribeiro, A., Pfaff, D. W., and Ågmo, A. (2010). The role of the estrogen receptor $\alpha$ in the medial amygdala and ventromedial nucleus of the hypothalamus in social recognition, anxiety and aggression. Behav. Brain Res. 210, 211-220. doi: 10.1016/j.bbr.2010. 02.033

Sulzer, D., Sonders, M. S., Poulsen, N. W., and Galli, A. (2005). Mechanisms of neurotransmitter release by amphetamines: a review. Prog. Neurobiol. 75, 406-433. doi: 10.1016/j.pneurobio.2005.04.003

Tennent, B. J., Smith, E. R., and Davidson, J. M. (1980). The effects of estrogen and progesterone on female rat proceptive behavior. Horm. Behav. 14, 65-75. doi: 10.1016/0018-506x(80)90016-1

Tetel, M. J., Getzinger, M. J., and Blaustein, J. D. (1993). Fos expression in the rat brain following vaginal-cervical stimulation by mating and manual probing. J. Neuroendocrinol. 5, 397-404. doi: 10.1111/j.1365-2826.1993. tb00500.x

Uphouse, L., Pinkston, J., Baade, D., Solano, C., and Onaiwu, B. (2015). Use of an operant paradigm for the study of antidepressant-induced sexual dysfunction. Behav. Pharmacol. 26, 697-705. doi: 10.1097/fbp.0000000000000177

Weigel, N. L., Bai, W., Zhang, Y., Beck, C. A., Edwards, D. P., and Poletti, A. (1995). Phosphorylation and progesterone receptor function. J. Steroid Biochem. Mol. Biol. 53, 509-514. doi: 10.1016/0960-0760(95)00098-K 
Weigel, N. L., and Moore, N. L. (2007). Kinases and protein phosphorylation as regulators of steroid hormone action. Nucl. Recept. Signal. 5:e005. doi: $10.1621 /$ nrs. 05005

Whalen, R. E. (1974). Estrogen-progesterone induction of mating behavior in female rats. Horm. Behav. 5, 157-162. doi: 10.1016/0018-506x(74)90040-3

Williams, K. M., and Mong, J. A. (2017). Methamphetamine and ovarian steroid responsive cells in the posteriodorsal medial amygdala are required for methamphetamine-enhanced proceptive behaviors. Sci. Rep. 7:39817. doi: $10.1038 /$ srep39817

Williams, K. M., Rudzinskas, S. A., and Mong, J. A. (2018). Methamphetamine administration increases proceptive behavior by activating src kinase and upregulating progesterone receptor in the medial amygdala. bioRxiv [Preprint]. doi: $10.1101 / 475616$

Winland, C., Haycox, C., Bolton, J. L., Jampana, S., Oakley, B. J., Ford, B., et al. (2011). Methamphetamine enhances sexual behavior in female rats. Pharmacol. Biochem. Behav. 98, 575-582. doi: 10.1016/j.pbb.2011.03.001
Zhang, L., Lou, D., Jiao, H., Zhang, D., Wang, X., Xia, Y., et al. (2004). Cocaine-induced intracellular signaling and gene expression are oppositely regulated by the dopamine D1 and D3 receptors. J. Neurosci. 24, 3344-3354. doi: 10.1523/jneurosci.0060-04.2004

Conflict of Interest Statement: The authors declare that the research was conducted in the absence of any commercial or financial relationships that could be construed as a potential conflict of interest.

Copyright (c) 2019 Rudzinskas, Williams, Mong and Holder. This is an open-access article distributed under the terms of the Creative Commons Attribution License (CC BY). The use, distribution or reproduction in other forums is permitted, provided the original author(s) and the copyright owner(s) are credited and that the original publication in this journal is cited, in accordance with accepted academic practice. No use, distribution or reproduction is permitted which does not comply with these terms. 